\section{Mojsisovics von Mojsvar (1839-1907)}

Os October 18 occurs the centenary of the birth of the distinguished Austrian geologist and palaentologist Johann August Georg Edmund Mojsisovics von Mojsvar. The son of a surgeon, he studied law at Vienna, taking his doctor's degree in 1864. Three years later he entered the Geological Instituto with which ho was connected until his retirement in 1900 . From 1892 until 1900 he was vice-director of the Institute. His first geological tours were taken in tho Salzkammergut with his famous teacher Suess. For more than thirty years ho devoted much attention to the Austrian Trias and among his principal writings was his work entitled "The Dolomite Reefs of South Tyrol" published in 1879. He was instrumental in furthering the systematic collection of fossils from the Eastern Alps, and his own work on the Cephalopods, said von Zittel, "is an achievement of permanent value and general scientific interest", conferring a boon on Alpine geology and zoological knowledge. For many years, with Melchior Neumayr (1845-90) he conducted the Beiträge zur Paloontologie und Geologie Oesterreich-Ungarus; and he assisted in founding the Austrian and German Alpine Clubs. Ho died at Mallnitz on October 2, 1907.

\section{William Morrant Baker (I839-r896)}

Mr. William, Morrant Baker, a prominent Isondon surgeon of the pre-aseptic era, was born on October 20, 1839, at Andover, where he was educated at the Grammar School. He received his medical training first by serving as an apprentice to a local surgeon and later entered as a student at St. Bartholomew's Hospital, Isondon. He obtained the qualification of MI.R.C.S. in 1864, and became F.R.C.S. in 1867. Botween the years 1862 and 1892 he obtained a number of appointments at his hospital, including those of demonstrator of anatomy, lecturer in physiology, surgeon to the skin department, casualty surgeon, assistant surgeon and full surgeon. He was also surgeon to the Evelina Hospital for Children, examiner for the Royal College of Surgeons and of the Universities of London and Durham, and associate editor of Kirke's "Handbook of Physiology". Ho retired from the staff of St. Bartholomew's Hospital in 1892. Under the term of "Baker's cysts" his name is attached to hernial protrusions of the synovial membrane of a joint through an aperture in its fibrous capsule. Ho also invented a flexible tube of red rubber for tracheotomy which is named after him.

\section{Animals during War-time}

Tue importance of safeguarding animal life under war conditions has been fully realized by the Government and $a$ useful and effective scheme has been worked out. The Home Office has appointed a National Air Raids Precautions Animals Committee. In each district or danger zone, all the local veterinary surgeons and the animal clinics and depots of the local animal welfaro societies aro co-operating under regional organizers appointed by the Home Office. These regional organizers are usually qualified veterinary surgeons. The Government A.R.P. Fandbook No. 12 dealing specially with animals has been widely circulated, and the People's Dispensary for Sick Animals purchased 100,000 copies for free distribution to people who cannot afford them.

Ix. a circular just issued to its members, the Zoological Society of London directs attention to the "many grave problems" war conditions have brought to its collections, which include a serious drop in revenue. Drastic staff and general expenditure reductions have been made; the aquarium has been closed owing to the danger of air-raids breaking the glass tanks, and the reptile and tortoiso houses aro being closed to avoid the expenso of heating them. A beginning has been made in tho destruction of animals, and substitute foodstuffs not required for national needs are being used for the nucleus collec. tion it is hoped to preserve. The North of England Zoological Society has so far withheld the destruction of its collection at Chester Zoo, and under an 'adoption' scheme has already had the cost of upkeep of many of its animals promised under weekly sub. scriptions, some for the duration of the war, from animal-lovers over a wide area. It has recently accepted a large donation of waterfowl and geeso from Mr. S. P. B. Freme, and a foreign bird collection. It has used its educational valuo by admitting thousands of evacuees free. Dudley Zoo has offered most of its animals for sale.

\section{National Rat Week}

Is view of the serious depredations on food stocks by rats, tho Ministry of Agriculturo and Fisheries considers that the annual Rat Week should bo held this year notwithstanding the war. Tho Week will begin on November 6, and the Minister asks everyono to make a special effort during the week to destroy any rats on their own lands and premises and to take all possible steps towards securing concerted action against these vermin. The Rats and Mice (Destruction) Act, 1919, places an obligation upon every occupier of 'Iand', which term includes buildings on or under land, to take steps to destroy rats and mice on the property which he occupies and to prevent such property from becoming infested. T'he Ministry's Advisory weaflet No. 49-"The Destruction of Rats and Mice" contains information and advice on methods for dealing with rats. A copy may be obtained free of charge from the Offices of the Ministry, 10 Whitehall Place, London, S.IV.I. Further information on the subject of rats is contained in Bulletin No. 30, "Rats and How to Exterminate Them", copies of which are obtainablo through any bookseller, or direct from H.M. Stationery Office, York House, Kingsway, London, W.C.2, price $6 d$. (7d. post paid).

\section{First Aid Posts and Workers}

A VERx useful "Memorandum for the Guidance of Medical Officers and other Personnel at First Aid Posts" has been issued by the Ministry of Health (H.M. Stationery Office. 3d. net). The functions and 